\title{
Return to Neverland: Shifting Baselines Affect Eutrophication Restoration Targets
}

\author{
Carlos M. Duarte • Daniel J. Conley • \\ Jacob Carstensen • María Sánchez-Camacho
}

Received: 19 July 2008 /Revised: 6 October 2008 / Accepted: 9 October 2008 /Published online: 30 October 2008

(C) Coastal and Estuarine Research Federation 2008

\begin{abstract}
The implicit assumption of many scientific and regulatory frameworks that ecosystems impacted by human pressures may be reverted to their original condition by suppressing the pressure was tested using coastal eutrophication. The response to nutrient abatement of four thoroughly studied coastal ecosystems that received increased nutrient inputs between the 1970s and the 1980s showed that the trajectories of these ecosystems were not directly reversible. All four ecosystems displayed convoluted trajectories that failed to return to the reference status upon nutrient reduction. This failure is proposed to result from the broad changes in environmental conditions, all affecting ecosystem dynamics, that occurred over the 30 years spanning from the onset of eutrophication to the reduction of nutrient levels. Understanding ecosystem response to multiple shifting baselines is essential to set reliable targets for restoration efforts.
\end{abstract}

Keywords Eutrophication - Baselines - Global change Nutrients

C. M. Duarte $(\bowtie) \cdot M$. Sánchez-Camacho Instituto Mediterráneo de Estudios Avanzados, IMEDEA (CSIC-UIB),

Miquel Marqués 21,

07190 Esporles, Spain

e-mail: carlosduarte@ifisc.uib.es

\section{J. Conley}

GeoBiosphere Science Centre, Department of Geology,

Lund University,

Sölvegatan 12,

22362 Lund, Sweden

J. Carstensen

National Environmental Research Institute,

Department of Marine Ecology, Aarhus University,

Frederiksborgvej 399,

4000 Roskilde, Denmark

\section{Introduction}

Widespread ecosystems degradation due to mounting human pressures has prompted efforts to reverse this process. These efforts are guided by the identification of the pressures responsible for the deterioration of the ecosystems and a target or reference status to which the ecosystem is supposed to return upon reduction of the pressures. Whereas scientific research has made tremendous progress in the first domain, the definition of a reference status to be achieved upon release of direct anthropogenic pressures remains a major stumbling block. In the absence of sound scientific principles, many legal and managerial frameworks refer to tentative assessments of the status of the ecosystems prior to the onset of significant pressures to set these targets, e.g., EC Water Framework Directive (EC 2000), US Clean Water Act (USEPA 2002)

J.M. Barrie, author of the celebrated children's play Peter Pan and Wendy (1911), created an island, Neverland, where everything remained perpetually unchanged. We submit that the expectation that ecosystems can be returned to an idealized past reference status by virtue of reducing direct human pressures is as likely as the existence of Neverland. We argue that concurrent changes, human-induced and otherwise, lead to shifting baselines imposing dynamic trajectories for reference ecosystem status.

We illustrate this problem using the outcome of efforts to reduce coastal eutrophication. Coastal eutrophication, derived from increased nutrient inputs, is a mounting threat to coastal waters worldwide (Nixon 1995; Vidal et al. 1999). Boesch (2002) reported that $67 \%$ of the combined surface area of US estuaries exhibited moderate to high degrees of eutrophication and a similar picture has emerged in Europe (Conley et al. 2002; Escaravage et al. 2006; Vidal et al. 1999) and other continents (e.g., Asia, Oceania; Boesch 
2002). The effects of eutrophication include the development of noxious blooms of opportunistic algae and toxic algae, the development of hypoxia, loss of valuable seagrasses, and in general a deterioration of the ecosystem quality and the services they provide (Boesch 2002; Cloern 2001; Duarte 1995; Nixon 1995).

The causes of coastal eutrophication are often bound within the coastal ecosystems and their watersheds and are, therefore, amenable to intervention at the individual ecosystem scale. Indeed, efforts to reduce nutrient inputs have resulted in a shift in trajectories, with many coastal systems entering, beginning in the 1990s, an oligotrophication phase (e.g., Boesch 2002; Carstensen et al. 2006; Cloern 2001). Reduced nutrient inputs have lead to improved water quality in some ecosystems, as reflected, for instance, in reduced chlorophyll a (chla) concentration following reduced nutrient inputs to Tampa Bay (Greening and Janicki 2006) and the Patuxent and Potomac Rivers (Kemp et al. 2005). Yet, reducing nutrient inputs does not always yield the expected ecosystem benefits (Colijn and Cadée 2003; Paerl et al. 2004; Philippart and Cadée 2000). For instance, changes in oceanographic forcing in San Francisco Bay were reported to lead to food web changes resulting in increased phytoplankton biomass despite a parallel decline in nutrient inputs (Cloern et al. 2007). Hence, responses of coastal ecosystems to oligotrophication may be more complex than expected as other control factors maybe changing at the same time.

Indeed, the published literature contains a diversity of responses to eutrophication and oligotrophication, indicating that changes in nutrient inputs are not the sole driver of changes in algal biomass in coastal waters. This diversity of responses include ecosystems that do not respond, or respond only minimally, to increasing nutrients because other factors are controlling chlorophyll, such as rapidly flushing, nonstratifying, light-limited estuaries like Delaware Bay (e.g., Sharp 1994) and northern San Francisco Bay (e.g., Dugdale et al. 2007). In addition to the spread of eutrophication, global change has also altered key baselines affecting the functioning of costal ecosystems and their food webs, such as increased $\mathrm{CO}_{2}$, warming, sea level rise, depletion of fisheries resources, habitat loss, among others (Table 1). The ongoing shift in these important baselines implies that the response of coastal ecosystems to oligotrophication may deviate from a simple reversion of the changes experienced during the earlier eutrophication phase. Indeed, the trajectory of ecosystems in a nutrient input versus algal biomass space is expected to be far more complex than the simpler proportional response implicit in many managerial schemes.

We consider here four scenarios, in increasing complexity, of ecosystem trajectories during eutrophication and subsequent oligotrophication. A first scenario that we depict as "Return to Neverland," embedded in most restoration and legislation frameworks, depicts the trajectories as being simple and reversible, resulting from direct deterministic control of ecosystem status by nutrient inputs (Fig. 1a). Consideration of shifting baselines (Table 1) implies that oligotrophication will deliver the coastal ecosystem to a different status, for the same nutrient input, than it had before eutrophication began, the "Shifting Baselines" scenario (Fig. 1c). More sophisticated analyses of ecosystem response to pressures include the presence of thresholds in nutrient inputs beyond which coastal ecosystems abruptly shift regimes (e.g., from seagrass-dominated to ecosystems devoid of benthic vegetation; Webster and Harris 2004), as demonstrated for a broad range of ecosystems (Scheffer et al. 2001). This "Regime Shift" scenario involves a resistance of the ecosystems to return to the original status during oligotrophication (Fig. 1b) due to hysteresis resulting from nonlinearities in the ecosystems (Kemp et al. 2005; Scheffer et al. 2001). The "Regime Shift" scenario considers coastal ecosystems to flip between alternative stable states, whereas no states are necessarily stable under a shifting baselines scenario. Thus, a final and more complex scenario considers the combined effects of shifting baselines and ecological thresholds acting to deliver the ecosystem, after extended time lags and through convoluted trajectories, to a substantially different status following oligotrophication, the "Regime Shift and Shifting Baselines" scenario (Fig. 1d).

We examined the adequacy of these scenarios to describe the trajectories followed by the mean chlorophyll a concentration, a powerful indicator of ecosystem response to nutrient inputs (Cloern 2001; Duarte 1995; Nixon 1995), using four thoroughly studied coastal ecosystems where significantly increased nutrient inputs, eutrophication phase, were followed by nutrient abatement significantly reducing nutrient inputs, oligotrophication phase.

\section{Materials and Methods}

We searched the literature for thorough time-series studies documenting statistically significant (linear regression analysis, $p<0.05$ ) trends towards increasing nutrient inputs to coastal ecosystems, eutrophication, followed by a statistically significant decline in nutrient inputs, oligotrophication, in response to deliberate managerial actions to reduce nutrient inputs. Whereas eutrophication or oligotrophication phases have been reported for many coastal ecosystems, both these phases are seldom reported for the same ecosystem; the length and intensity of the studies are insufficient to deliver statistically significant eutrophication and/or oligotrophication phases, or changes in nutrient concentrations were unrelated to changes in anthropogenic 
Table 1 Global changes in human activity and key environmental traits between 1970, the onset of coastal eutrophication research, and 2005

\begin{tabular}{|c|c|c|c|c|}
\hline Property & 1970 & 2005 & Potential effects & References \\
\hline $\mathrm{CO}_{2}$ emissions $\left(\mathrm{Pg}_{\text {year }}{ }^{-1}\right)$ & 4.1 & 7.8 & $\begin{array}{l}\text { Climate warming, increased photosynthetic } \\
\text { rates, ocean acidification }\end{array}$ & Forster et al. (2007) \\
\hline Atmospheric $\mathrm{CO}_{2}(\mathrm{ppm})$ & 326 & 376 & $\begin{array}{l}\text { Climate warming, increased photosynthetic } \\
\text { rates, ocean acidification }\end{array}$ & Forster et al. (2007) \\
\hline Human population (million) ${ }^{\mathrm{a}}$ & 3,698 & 6,514 & Increased appropriation of natural resources & $\begin{array}{l}\text { UN population } \\
\text { database (UN 2006) }\end{array}$ \\
\hline Freshwater withdrawal $\left(\mathrm{km}^{3}\right.$ year $\left.{ }^{-1}\right)$ & 2,584 & $5,917(1)$ & $\begin{array}{l}\text { Reduced runoff, salinization of coastal } \\
\text { aquifers, deteriorated water quality }\end{array}$ & Shiklomanov (2003) \\
\hline Food production on land (million tons) ${ }^{\mathrm{a}}$ & 4,640 & 8,666 & $\begin{array}{l}\text { Increased cropland and pasture area, } \\
\text { increased fertilizer use, increased pesticide use }\end{array}$ & FAO (2006) \\
\hline Fertilizer use (million tons $\mathrm{N}$ year $\left.{ }^{-1}\right)^{\mathrm{a}}$ & 32 & 88 & $\begin{array}{l}\text { Increased eutrophication of freshwater } \\
\text { and coastal waters }\end{array}$ & Smil (2002) \\
\hline $\begin{array}{l}\text { Mean global temperature } \\
\left({ }^{\circ} \mathrm{C} \text {, relative to } 1961-1990 \text { mean }\right)\end{array}$ & -0.12 & +0.45 & $\begin{array}{l}\text { Increased respiration, reduced oxygen content } \\
\text { of waters, increased stratification, species shift }\end{array}$ & Forster et al. (2007) \\
\hline $\begin{array}{l}\text { Mean global sea level (mm, } \\
\text { relative to } 1961-1990 \text { mean) }\end{array}$ & -10 & 68 & $\begin{array}{l}\text { Increased coastal erosion, increased salinization } \\
\text { of coastal aquifers }\end{array}$ & Bindoff et al. (2007) \\
\hline $\begin{array}{l}\text { Fish and invertebrate taxa lost from large } \\
\text { marine ecosystems (\% relative to } 1950)\end{array}$ & $5-17 \%$ & $20-80 \%$ & Disruption of food webs and ecosystem processes & Worm et al. (2006) \\
\hline Fisheries landings (million tons) & 63.7 & 96.4 & Marine food web changes, increased eutrophication & FAO (2006) \\
\hline $\begin{array}{l}\text { Marine aquaculture production } \\
\text { (million tons) }^{\mathrm{a}}\end{array}$ & 2.2 & 33.6 & Increased eutrophication of coastal waters & FAO (2006) \\
\hline Arable land $\left(10^{6} \mathrm{~km}^{2}\right)^{\mathrm{a}}$ & 13.2 & 14.2 & $\begin{array}{l}\text { Increased eutrophication and siltation of } \\
\text { coastal waters }\end{array}$ & FAO (2006) \\
\hline
\end{tabular}

${ }^{\text {a }}$ Changes that affect nutrient inputs to coastal waters

inputs. The four best-documented cases we found were Marsdiep, The Netherlands; Helgoland, Germany; Odense Fjord, Denmark; and Gulf of Riga, Latvia/Estonia. The eutrophication period encompassed the period from the 1970 s to the mid to late $1980 \mathrm{~s}$, and the oligotrophication phase started in the 1990s. These were indeed the only cases we could find that showed both statistically significant eutrophication and subsequent oligotrophication phases (inserts in Fig. 2).

For the Marsdiep example, annual means of chla from De Jonge (1997) were updated with recent data from the Dutch national monitoring program (www.waterbase.nl). Total nitrogen inputs from Lake Ijssel discharging to the Marsdiep were obtained by intercalibrating data (19721992) from De Jonge (1997) with data (1977-2002) from Paetsch and Lenhart (2004) using linear regression.

Phytoplankton carbon biomass for Helgoland was provided by the Alfred Wegener Institute at Helgoland. Biomass of the dominating functional group, diatoms, was used only because flagellate data have been subject to systematic errors (Paetsch and Lenhart 2004). Nutrient inputs (1978-2006) and freshwater discharge (1874-2006) from the Elbe River, the largest contributor of many rivers to the southeastern North Sea, were provided by ARGE ELBE. Nutrient inputs between 1962 and 1997 were reconstructed by estimating a transfer function (similar to
Conley et al. 2007) of nitrogen surplus in the watershed (Hussain et al. 2004) multiplied by freshwater discharge after subtracting point sources (approximately 37\%).

Nitrogen input (entire watershed) and chla data for Odense Fjord were obtained from Fyns county in Denmark.

For the Gulf of Riga, chla data were provided by the Latvian Institute of Aquatic Ecology, University of Latvia, and nutrient input from the Daugava River (largest source of nutrients) was from Laznik et al (1999), with updated data from ICES (2007). Smoothed curves were obtained by 5-year central moving averages.

\section{Results}

The four ecosystems experienced broad changes in nutrient (three to fivefold range) and algal biomass (three to tenfold) along the eutrophication and subsequent oligotrophication periods (Fig. 2). Neither one of the four ecosystems examined reached chlorophyll a concentrations above $16 \mu \mathrm{g} / \mathrm{L}$, indicating that they did not reach hypereutrophic conditions, and their corresponding trajectories may not be representative of more heavily eutrophied coastal systems.

The Marsdiep ecosystem experienced a clear, significant increase in nutrient inputs from 1970 to the mid 1980s, followed by a significant reduction in nutrient inputs to 


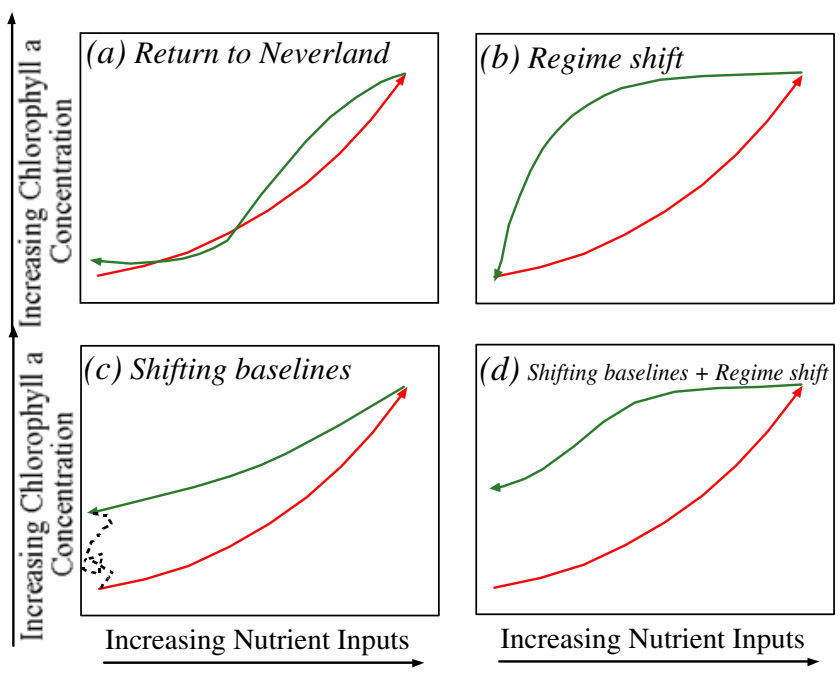

Fig. 1 Idealized trajectories of chlorophyll a concentrations, as an indicator of ecosystem status, and nutrient inputs to coastal ecosystems under increasing (red line) and decreasing (green line) nutrient inputs under different response scenarios: a "Return to Neverland" scenario implying a direct reversible relationship between chlorophyll a concentrations and nutrient inputs; $\mathbf{b}$ a trajectory resulting from a "Regime Shift" in ecosystem status in response to nutrient inputs. This trajectory results in an apparent time lag, or hysteresis effect, in the response to reducing nutrient inputs; c "Shifting Baselines" scenario, where changes in forcing factors other than nutrients (e.g., climate, food web structure) forces a trajectory for the ecosystem independent of that forced by nutrients, depicted by the dotted line, preventing the ecosystem to return to the "reference condition" after reducing nutrient inputs; and $\mathbf{d}$ a trajectory displaying "Regime Shift and Shifting Baselines" combined

reach values comparable to those in the early 1970 s (Fig. 2a). Chlorophyll a increased rapidly following increased nutrient inputs and declined equally rapidly during the initial phase of the oligotrophication period. However, chlorophyll a concentration level off with subsequent oligotrophication at levels almost twice as high as those observed under similar nutrient inputs at the onset of the eutrophication phase (Fig. 2a).

The Helgoland ecosystem experienced a doubling of nitrogen inputs between 1960 and 1980, followed by an oligotrophication phase involving an abrupt decline followed by a more gradual decline in nutrient inputs over the past decade (Fig. 2b). The biomass of diatoms showed, as for the Marsdiep, a clear increase during the eutrophication phase followed by an initial decline during the oligotrophication phase and a recent increase in diatom biomass despite sustained oligotrophication (Fig. 2b).

The Odense fjord experienced a rapid eutrophication during the late 1980s followed by a more gradual, still ongoing oligotrophication to reach nutrient inputs below those recorded at the onset of the monitoring program (Fig. 2c). The sixfold change in chlorophyll a concentration along this record did not follow any consistent pattern with the eutrophication and oligotrophication phase, resulting in a very complex trajectory (Fig. 2c).

The pattern of eutrophication and oligotrophication in the Gulf of Riga closely resembled that in the Marsdiep ecosystem (Fig. 2d). However, the increase in chlorophyll a concentration was far more modest and there was no clear decline in chlorophyll a concentration along the oligotrophication phase (Fig. 2d).

The four ecosystems examined followed a diversity of complex phytoplankton biomass trajectories during the eutrophication and oligotrophic phases, which appeared to be rather idiosyncratic among ecosystems (Fig. 2). Only after considerable smoothing of the time trajectories did some pattern emerge (Fig. 2). Whereas phytoplankton biomass generally increased with increasing nutrient inputs, the trajectory during the oligotrophication phase did not follow an inverse path. Indeed, the pattern observed deviates in all four ecosystems from that expected under the "Return to Neverland" scenario (Fig. 1a), as none of the trajectories show evidence of a return of mean chlorophyll a concentrations to levels comparable to those observed at the onset of the time series following reduction of nutrient inputs to comparable, or lower, levels (Fig. 2, inserts). The smoothed trajectories (Fig. 2) resemble, instead, those expected under the combined "Regime Shift and Shifting Baselines" scenario (Fig. 1d).

\section{Discussion}

The observation of complex trajectories of coastal ecosystems in response to eutrophication and subsequent oligotrophication suggests that the expectation that eutrophication can be reverted back to historical reference values by reducing nutrient inputs alone may be unsupported, as oligotrophication does not seem to be occurring to the expected extent. Ad hoc explanations are typically offered to account for failure of coastal ecosystems to return to reference status upon reducing nutrient inputs (e.g., alternative nutrient sources, internal loading, shifts in limiting nutrients, colimitation effects of nutrients and light, decreased filter-feeders activity, e.g., Colijn and Cadée 2003; Paerl et al. 2004; Philippart and Cadée 2000). A decline in chlorophyll a concentration in moderately eutrophic coastal ecosystems may be triggered by factors other than oligotrophication, particularly through changes in food web structure (e.g., Heck and Valentine 2007; Cloern 2001). These observations are comparable to the much longer experience in reverting lake eutrophication. Lake ecosystems have been reported to follow convoluted trajectories following nutrient reduction, with internal loading, changes in food webs, the impacts of climate change, and 10-15-year time lags from nutrient reduction 


\section{A}

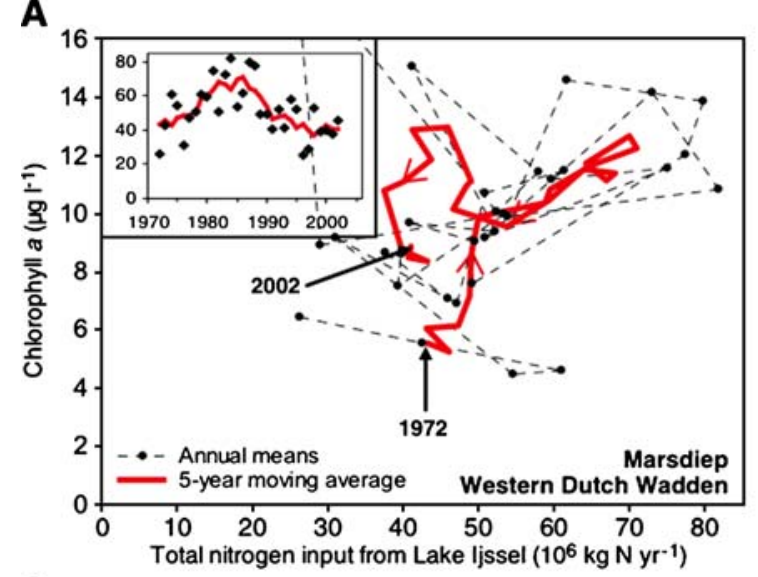

C

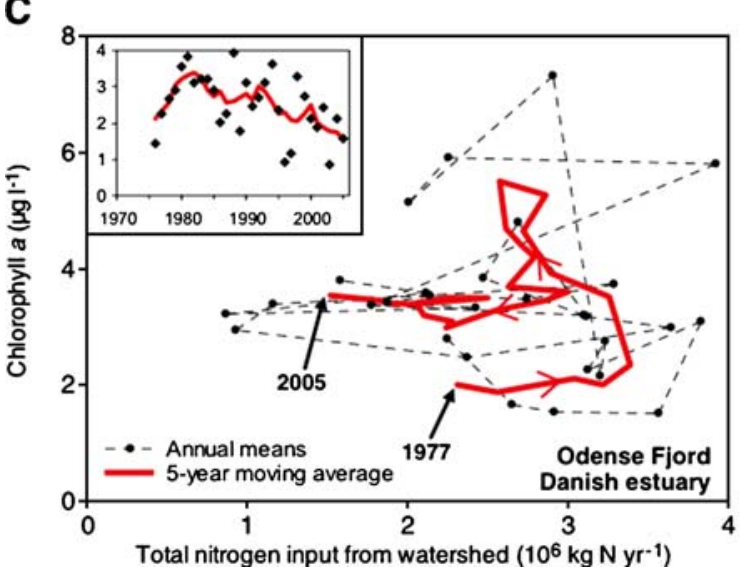

Fig. 2 Sample trajectories of annual means of chlorophyll a concentrations and diatom carbon biomass, as a proxy of ecosystem status, versus total nitrogen loading, of four intensively studied Northern European coastal ecosystems that experienced significant eutrophication followed by significant oligotrophication after management actions $(\mathbf{a}-\mathbf{c})$ or breakdown of economies in Eastern Europe

to reduced algal biomass put forward as the causes for the complex lake trajectories observed (Jeppesen et al. 2005).

We submit that the expectation that ecosystems will return to the original conditions tracking reversed trajectories following reduced nutrient inputs may be fundamentally flawed, as it ignores the consequences of shifting baselines, deriving from concurrent changes in multiple pressures, along the time elapsed between pressures and restoration (about 30 years, Table 1). For instance, historical overfishing has altered coastal food webs, removing ecological buffers (Duarte 1995) and rendering coastal ecosystem more prone to eutrophication (e.g., Heck and Valentine 2007; Jackson et al. 2001). Environmental changes induced by human activity, superimposed upon natural trends and fluctuations, have led to major, extreme, and unprecedented changes in the environment since coastal eutrophication emerged in the 1970s that could potentially affect the trophic status of coastal waters (Table 1). These changes are of such magnitude and simultaneously affect so many fundamental factors affecting the functioning of coastal ecosystems that
B

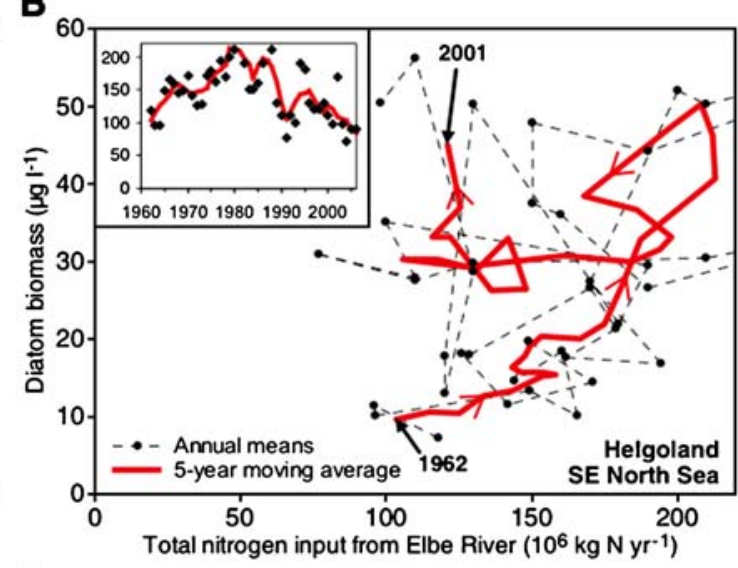

D

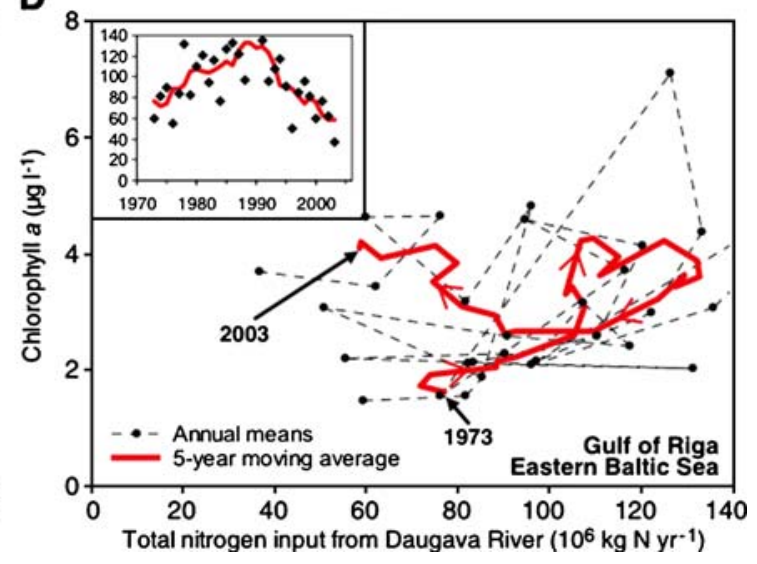

(b and d). The full black symbols show the annual average values and the red line follows the trajectory of a 5-year moving average. Initial and final years of the time series are indicated. Inserts show the time series and 5-year running average of total nitrogen inputs to the ecosystems. Note the difference in scaling

they would have forced, through the combination of their separate and synergetic effects, coastal ecosystems to drift away from their "reference" status even in the absence of direct anthropogenic nutrient inputs.

Failure of coastal ecosystems to return to past ecological conditions upon significant reduction in nutrient inputs is disturbing both to scientists and managers, as current models and management frameworks (e.g., EU Water Framework Directive, EC 2000) assume a direct, continuous response of coastal ecosystems to altered nutrient inputs. These frameworks are derived from the widespread observation of water quality and ecosystem deterioration upon increasing nutrient inputs (e.g., Boesch 2002; Nixon 1995) and implicitly assume that opposite trajectories would be followed upon nutrient reduction, returning the ecosystems to acceptable deviation from preexisting reference conditions (e.g., EU Water Framework Directive, EC 2000). Lack of recovery of coastal ecosystems following reduced nutrient inputs is likely to create frustration, potentially leading to inaction when targets of ecosystem 
restoration efforts fail to be met. The scientific community is to bear much of the burden for the frustration of managers and society in general when confronted with failure to restore eutrophied ecosystems, as the role of nutrient inputs in controlling phytoplankton biomass has been generally oversimplified in the dialog between scientists and managers, possibly driven by the benign intention to deliver a message clear enough as to prompt restoration efforts. Thorough, sophisticated accounts of the interplay between nutrient inputs and other factors, intrinsic and extrinsic to the ecosystems, in controlling phytoplankton biomass abound in the scientific literature (e.g., Cloern 2001; Jackson et al. 2001; Sharp 2001; Wilkerson et al. 2006; Howarth and Marino 2006) but have not been effectively communicated to managers and policy makers.

Emphasis in returning ecosystems to a particular past state, an unlikely outcome in a world of shifting baselines, should be replaced by targets ensuring the maintenance of key ecosystem functions and, thereby, the constant supply of valuable ecosystem services to society. For instance, the examination of the four cases presented may be interpreted as evidence that nutrient reduction was ineffective. Yet, reduced nutrient inputs have halted further eutrophication, reducing associated damage and vulnerabilities, and improved some indicators of ecosystem status in many ecosystems (e.g., oxygen levels, macrophyte cover; Carstensen et al. 2006; Kemp et al. 2005). Moreover, the literature also contains examples of ecosystems that did improve following reduced nutrient inputs, such as Tampa Bay (Greening and Janicki 2006) or the Potomac River (Kemp et al. 2005). Hence, efforts to reduce nutrient inputs to eutrophied coastal ecosystems have indeed delivered important benefits by either leading to an improved status of coastal ecosystems or preventing damages and risks associated to further eutrophication.

The apparent lack of a common trajectory of coastal ecosystems represents a major challenge for scientists but also for managers and policy makers, who must consider the possible occurrence of shifting baselines and regime shifts in the ecosystems to evaluate possible outcomes of restoration efforts. Managers, and the public at large, must be educated to accommodate the possibility that ecosystem responses may display hysteresis, due to time lags in the responses and nonlinearities in the system, in the expected outcomes of managerial interventions (Kemp et al. 2005), so that expectations include observed ecosystem responses. It is, however, critical that scientific understanding of ecosystem trajectories progresses to identify what ecosystem traits determine the likelihood of individual coastal ecosystem to show the different trajectories proposed here (Fig. 1) in response to reduced nutrient inputs, to better inform managerial decisions. More generally, the scientific underpinnings of ecosystem restoration efforts must prog- ress to reach the capacity to forecast the trajectories of ecosystems subject to multiple simultaneous pressures and changes, thereby considering the dynamic nature of reference conditions. This requires a dynamic approach to ecosystem responses, considering not only direct responses to pressures but also random drifts, shifting baselines, and nonlinear effects. Ecological thresholds must be identified, also providing boundaries for management strategies, and methods to identify these without the need to cross them are urgently needed (Strange 2007).

The impact of shifting baselines on the capacity to return ecosystems to an idealized past reference status is not exclusive of coastal ecosystems but affects all domains of environmental restoration. An example is the failure to restore the ozone layer to levels before chlorofluorocarbon (CFC) release after the implementation of the Montreal Protocol in 1987, which has been argued to derive from the combined effects of climate warming and the release of new chemicals impacting on ozone levels (Weatherhead and Andersen 2006), illustrating the need to consider shifting baselines. As for nutrient reduction efforts, the decreased release of CFCs in the Montreal Protocol was not ineffective, as it prevented further deterioration of the ozone layer. The widespread aim of preserving ecosystems unchanged in protected areas, such as national parks, represents an effort to anchor them on the shores of Neverland against the action of shifting baselines and clearly irreversible events, such as species extinctions and invasions, which will likely be met with failure. Fisheries science has also faced a general failure to predict stock recovery following reduced fishing pressure, which has led to pleas for a more ecosystem-based approach to fisheries science and management (Botsford et al. 1997), which should consider community and food web interactions and the dynamic nature of marine ecosystems, including their responses to climate change. Similarly, coastal ecosystems must be managed from an ecosystems perspective that extends beyond the role of nutrient inputs to consider the concurrent dynamics of the drivers of change and their interactions.

Society, and its actors most directly involved in ecosystem stewardship, scientists, managers and policy makers, must reconsider the targets of their efforts to focus on maintaining a healthy environment, abandoning scenarios revolving around idealized Neverlands, to confront shifting baselines. Whereas we can reasonably predict the statistical trend that ecosystems will follow upon changes in nutrient inputs, we must acknowledge that our capacity to predict the trajectories of individual ecosystems is still primitive as is challenged by elements of idiosyncrasy in the individual responses that cannot be derived from the statistical responses of multiple coastal ecosystems. Confronted with the need to act to prevent further ecosystem deterioration, we must accept the limits to governability of 
coastal ecosystems and the need to consider some degree of what Jentoft, addressing similar failures to manage fisheries, has referred to as "a technology of foolishness," which emphasizes institutional experimentation and learning by doing (Jentoft 2007).

There is a major pending revolution in concepts, paradigms, and approaches in the way we manage nature that should no longer strive at delivering a planet to future generations identical to that we experienced at one point of our lives but one that maintains functional integrity and services of ecosystems conducive to a sustainable future. Ecology and restoration science must, as the character Wendy in J.M. Barrie's play, grow to face change.

Acknowledgements This research is a contribution to the Thresholds Integrated Project, funded by Framework Program 6 of the European Commission (contract \# 003933-2) and COMPACT, a Marine Curie Chair for Daniel Conley (MEXC-CT-2006-042718). We thank Karen Wiltshire (AWI Helgoland), Michael Bergemann (ARGE ELBE), Jørgen Windolf (National Environmental Research Institute), and Bärbel Müller-Karulis (Latvian Institute of Aquatic Ecology) for supplying data and J. Cloern, L. McManus, and two anonymous reviewers for useful comments.

\section{References}

Barrie, J. M. (1911). Peter Pan and Wendy. London.

Bindoff, N.L. et al 2007. Observations: Oceanic climate change and sea level. In Climate change 2007: The physical science basis. Contribution of working group I to the fourth assessment report of the intergovernmental panel on climate change, eds. S. Solomon, D. Qin, M. Manning, Z. Chen, M. Marquis, K.B. Averyt, M. Tignor, H.L. Miller. Cambridge: Cambridge University Press.

Boesch, D.F. 2002. Challenges and opportunities for science in reducing nutrient over-enrichment of coastal ecosystems. Estuaries 25: 886-900. doi:10.1007/BF02804914.

Botsford, L.W., J.C. Castilla, and C.H. Peterson. 1997. The management of fisheries and marine ecosystems. Science 277: 509-515. doi:10.1126/science.277.5325.509.

Carstensen, J., D.J. Conley, J.H. Andersen, and G. Ærtebjerg. 2006. Coastal eutrophication and trend reversal: A Danish case study. Limnology and Oceanography 51: 398-408.

Cloern, J.E. 2001. Our evolving conceptual model of the coastal eutrophication problem. Marine Ecology Progress Series 210: 223-253. doi:10.3354/meps210223.

Cloern, J.E., A.D. Jassby, J.K. Thompson, and K.A. Hieb. 2007. A cold phase of the East Pacific triggers new phytoplankton blooms in San Francisco Bay. Proceedings of the National Academy of Sciences 104: 18561-18565. doi:10.1073/pnas.0706151104.

Colijn, F., and G.C. Cadée. 2003. Is phytoplankton growth in the Wadden Sea light or nitrogen limited? Journal of Sea Research 49: 83-93. doi:10.1016/S1385-1101(03)00002-9.

Conley, D.J., J. Carstensen, G. Ærtebjerg, P.B. Christensen, T. Dalsgaard, J.L.S. Hansen, and A. Josefson. 2007. Long-term changes and impacts of hypoxia in Danish coastal waters. Ecological Applications 17: S165-S184. doi:10.1890/05-0766.1.

Conley, D.J., S. Markager, J. Andersen, T. Ellermann, and L.M. Svendsen. 2002. Coastal eutrophication and the Danish national aquatic monitoring and assessment program. Estuaries 25: 848861. doi:10.1007/BF02804910.

De Jonge, V.N. 1997. High remaining productivity in the Dutch western Wadden Sea despite decreasing nutrient inputs from riverine sources. Marine Pollution Bulletin 34: 427-436. doi:10.1016/S0025-326X(96)00143-9.

Duarte, C.M. 1995. Submerged aquatic vegetation in relation to different nutrient regimes. Ophelia 41: 87-112.

Dugdale, R.C., F.P. Wilkerson, V.E. Hogue, and A. Marchi. 2007. The role of ammonium and nitrate in spring bloom development in San Francisco Bay. Estuarine Coastal Shelf Science 73: 17-29. doi:10.1016/j.ecss.2006.12.008.

EC. 2000. Directive 200/60/EC of the European parliament and of the council of 23 October 2000 establishing a framework for community action in the field of water policy.

Escaravage, V., P.M.J. Herman, and C.H.R. Heip. 2006. Nutrient dynamics in European water systems - the management perspective emerging from ELOISE, a European cluster of land-ocean interaction studies. Environmental Sciences 3: 97-112. doi:10.1080/15693430600659113.

FAO. (2006). FAO Statistics database. http://faostat.fao.org/. Accessed 10 June 2008.

Forster, P. et al 2007. Changes in atmospheric constituents and in radiative forcing. In Climate change 2007: The physical science basis. Contribution of working group I to the fourth assessment report of the intergovernmental panel on climate change, eds. S. Solomon, D. Qin, M. Manning, Z. Chen, M. Marquis, K.B. Averyt, M. Tignora, and H.L. Miller. Cambridge: Cambridge University Press.

Greening, H., and A. Janicki. 2006. Toward reversal of eutrophic conditions in a subtropical estuary: Water quality and seagrass response to nitrogen loading reductions in Tampa Bay, USA. Environmental Management 38: 163-178. doi:10.1007/s00267005-0079-4.

Heck, K.L., and J.F. Valentine. 2007. The primacy of top-down effects in shallow benthic ecosystems. Estuaries and Coasts 30: 371-381.

Howarth, R.W., and R. Marino. 2006. Nitrogen as the limiting nutrient for eutrophication in coastal marine ecosystems: Evolving views over 3 decades. Limnology and Oceanography 51: 364-376.

Hussain, M., A. Grimwall, and W. Petersen. 2004. Estimation of the human impact on nutrient loads carried by the Elbe River. Environmental Monitoring and Assessment 96: 15-33. doi:10.1023/B:EMAS.0000031722.88972.62.

ICES. (2007). Report of the ICES/HELCOM Working group on integrated assessments of the Baltic Sea (WGIAB), 12-16 March 2007. Hamburg, Germany: ICES. Report no. CM 2007/BCC:04.

Jackson, J.B.C. et al 2001. Historical overfishing and the recent collapse of coastal ecosystems. Science 293: 629-638. doi:10.1126/science.1059199.

Jentoft, S. 2007. Limits of governability: Institutional implications for fisheries and coastal governance. Marine Policy 31: 360-370. doi:10.1016/j.marpol.2006.11.003.

Jeppesen, R., M. Søndergaard, J.P. Jensen, K.E. havens, O. Anneville, L. Carvalho, M.F. Coveney, R. Deneke, M. Dokulil, B. Foy, D. Gerdeaux, S.E. Hampton, S. Hilt, K. Kangur, J. Köhler, E.H.H.R. Lammens, T.L. Lauridsen, M. Manca, M.R. Miracle, B. Moss, P. Noges, G. Persson, G. Phillips, R. Portielje, S. Romo, C.L. Schelske, D. Straile, I. Tatrai, E. Willen, and M. Winder. 2005. Lake responses to reduced nutrient loading - an analysis of contemporary long-term data from 35 case studies. Freshwater Biology 50: 1747-1771. doi:10.1111/j.1365-2427.2005.01415.x.

Kemp, W.M. et al 2005. Eutrophication of Chesapeake Bay: Historical trends and ecological interactions. Marine Ecology Progress Series 303: 1-29. doi:10.3354/meps303001.

Laznik, M., P. Stålnacke, A. Grimvall, and H.B. Wittgrend. 1999. Riverine input of nutrients to the Gulf of Riga - temporal and 
spatial variation. Journal of Marine Systems 23: 11-25. doi:10.1016/S0924-7963(99)00048-2.

Nixon, S.W. 1995. Coastal marine eutrophication-a definition, social causes, and future concerns. Ophelia 41: 199-219.

Paerl, H.W., L.M. Valdes, A.R. Joyner, and M.F. Piehler. 2004. Solving problems resulting from solutions: Evolution of a dual nutrient management strategy for the eutrophying Neuse river estuary, North Carolina. Environmental Science \& Technology 38: 3068-3073. doi:10.1021/es0352350.

Paetsch, J. and H. Lenhart. 2004. Daily loads of nutrients, total alkalinity, dissolved inorganic carbon and dissolved organic carbon of the European continental rivers for the years 1977 2002. ftp://ftp.ifm.uni-hamburg.de/pub/data/riverload/RIVERZMK-48.pdf. Accessed 14 July 2008.

Philippart, C.J.M., and C.G. Cadée. 2000. Was total primary production in the western Wadden Sea stimulated by nitrogen loading? Helgoland Marine Research 54: 55-62. doi:10.1007/s101520050002.

Scheffer, M., S. Carpenter, J.A. Foley, C. Folke, and B. Walker. 2001. Catastrophic shifts in ecosystems. Nature 413: 591-596. doi: $10.1038 / 35098000$.

Sharp, J.H. 1994. What not to do about nutrients in the Delaware Estuary. In Changes in fluxes in estuaries: Implications from science to management, eds. K.R. Dyer, and R.J. Orth, 423-428. Fredensborg: Olsen and Olsen.

Sharp, J.H. 2001. Marine and aquatic communities, stress from Eutrophication. In Encyclopedia of Biodiversity, ed. S. Levin, 4: 1-11. New York: Academic.

Shiklomanov, I.A. 2003. World water use and availability. In World water resources at the beginning of the twenty-first century, eds.
I.A. Shiklomanov, and J.C. Rodda, 369-389. Cambridge: Cambridge University Press.

Smil, V. 2002. Nitrogen and food production: Proteins for human diets. Ambio 31: 126-131. doi:10.1639/0044-7447(2002)031 [0126:NAFPPF]2.0.CO;2.

Strange, C.J. 2007. Facing the brink without crossing it. Bioscience 57: 920-926. doi:10.1641/B571103.

UN. (2006) UN population database. http://esa.un.org/unpp. Accessed 14 November 2007.

USEPA. (2002). Federal Water Pollution Control Act, United States Code.

Vidal, M., C.M. Duarte, and M.C. Sanchez. 1999. Coastal entrophication research in Europe: Progress and imbalances. Marine Pollution Bulletin 38: 851-854. doi:10.1016/S0025-326X(99)00030-2.

Weatherhead, E.C., and S.B. Andersen. 2006. The search for signs of recovery of the ozone layer. Nature 441: 39-45. doi:10.1038/ nature 04746.

Webster, I.T., and G.P. Harris. 2004. Anthropogenic impacts on the ecosystems of coastal lagoons: Modelling fundamental biogeochemical processes and management implications. Marine and Freshwater Research 55: 67-78. doi:10.1071/MF03068.

Wilkerson, F.P., R.C. Dugdale, V.E. Hogue, and A. Marchi. 2006. Phytoplankton blooms and nitrogen productivity in San Francisco Bay. Estuaries and Coasts 29: 401-416.

Worm, B., E.B. Barbier, N. Beaumont, J.E. Duffy, C. Folke, B.S. Halpern, J.B.C. Jackson, H.K. Lotze, F. Micheli, S.R. Palumbi, E. Sala, K.A. Selkoe, J.J. Stachowicz, R. Watson. 2006. Impacts of biodiversity loss on ocean ecosystem services. Science 314: 787-790. 